\title{
PENGARUH MODEL DISCOVERY LEARNING BERBANTUAN MEDIA AUDIOVISUAL TERHADAP KETERAMPILAN MENULIS TEKS ANEKDOT SISWA KELAS X SMA NEGERI 1 LEMBAH GUMANTI KABUPATEN SOLOK
}

\author{
Oleh: \\ Mayora ${ }^{1}$, Syahrul ${ }^{2}$, Tressyalina ${ }^{3}$ \\ Program Studi Pendidikan Bahasa dan Sastra Indonesia \\ FBS Universitas Negeri Padang \\ email: Mayorafatmasari21@gmail.com
}

\begin{abstract}
In this study, theoretical concept of discovery learning are reviewed the influence of discovery learning style use media audiovisual to assist students writing skill Anecdote text at X grade of SMA Negeri 1 Lembah Gumanti. The data collections of this study are results of use Anecdote writing skill text between an experiment and control class. The process of collecting data are use extend of learning anecdote skill text by discovery learning style with media audiovisual assistant both an experiment class. Test by anecdote writing skill text work show on students. The writing Anecdote skill text between an experiment and control class was researcher used to show there comparisons among the influence of discovery learning style with assist audiovisual media accompanying hypothesis experiment abbreviation. The results of this study showed that (1) using Anecdote writing skill text at students X Grade of SMA Negeri 1 Lembah Gumanti without use discovery learning style with assist media audiovisual have qualification kind. (2) That anecdote writing skill text at students X Grade of SMA Negeri 1 Lembah Gumanti without use discovery learning style with assist media audiovisual also have qualification kind. (3) Based on abbreviation hypothesis experiment there are significant conclusions of influence toward discovery learning style with assist media audiovisual on anecdote skill writing text on students learning process of SMA Negeri 1 Lembah Gumanti.
\end{abstract}

Kata kunci: Pengaruh, model discovery learning berbantuan media audiovisual, menulis teks anekdot

\section{A. Pendahuluan}

Keterampilan menulis teks anekdot adalah sebuah keterampilan dalam menulis teks yang menghibur dan bersifat lucu yang bertujuan untuk mengkritik seseorang. Wardani (2017:46) menyatakan bahwa teks anekdot merupakan sebuah cerita singkat, namun lucu dan isinya berupa sindiran. Senada dengan pendapat di atas, Nuryatin (2016:44) menyatakan bahwa anekdot adalah sebuah cerita lucu atau menggelitik yang bertujuan memberikan suatu pelajaran tertentu. Kisah dalam anekdot biasanya melibatkan tokoh tertentu yang bersifat faktual ataupun terkenal. Anekdot tidak hanya menjadikan hal-hal yang lucu, guyonan, ataupun humor, akan tetapi terdapat pula tujuan lain yaitu berupa pesan yang diharapkan bisa memberikan pelajaran kepada khalayak.

\footnotetext{
${ }_{1}^{1}$ Mahasiswa Penulis Skripsi Prodi Pendidikan Bahasa dan Sastra Indonesia untuk wisuda periode September 2017

2 Pembimbing I, dosen FBS Universitas Negeri Padang

3 Pembimbing II, dosen FBS Universitas Negeri Padang
} 
Hubungan Keterampilan Memahami Teks Cerita Pendek dengan Keterampilan Menulis Teks Cerita Pendek Siswa Kelas XI SMA Semen Padang- Mira Handriyani, Harris Effendi Thahar, Andria Catri Tamsin

Berdasarkan pendapat di atas, disimpulkan bahwa teks anekdot adalah teks cerita yang bersifat lucu dan bertujuan untuk menyindir seseorang atau suatu kebiasaan buruk. Cerita ini lahir dari imajinasi seseorang yang menceritakan peristiwa secara padat, singkat, jelas dan memiliki rangkaian peristiwa yang menimpa orang terkenal secara runtut.

Keterampilan siswa dalam menulis teks anekdot dapat dilihat dari kelengkapan struktur teks, kelengkapan isi teks, dan EBI yang tepat. Pertama, struktur teks anekdot, yaitu (1) abstraksi, (2) orientasi, (3) krisis, (4) reaksi, dan (5) koda (Kemendikbud 2013:101). Selanjutnya, Agustahina (2014:63-74) memberikan batasan terhadap struktur tersebut sebagai berikut. Pertama, abstraksi adalah bagian di awal paragraf yang berfungsi memberikan gambaran tentang isi teks. Biasanya bagian ini menunjukkan hal unik yang akan dipaparkan dalam teks. Kedua, orientasi adalah bagian yang menunjukkan awal kejadian cerita atau latar belakang terjadinya peristiwa. Biasanya, penulis bercerita dengan terperinci di bagian ini. Ketiga, krisis adalah bagian yang menjadi hal atau masalah unik atau tidak biasa terjadi pada si penulis atau orang yang diceritakan. Keempat, reaksi adalah bagian berisi cara penulis atau orang yang diceritakan menyelesaikan masalah yang timbul pada bagian krisis. Kelima, koda adalah bagian akhir cerita dari cerita unik tersebut. Biasanya berisi kesimpulan terkait keseluruhan isi teks.

Kedua, isi teks anekdot. Kemendikbud (2015:83), menyatakan di dalam isi teks anekdot ada beberapa hal yang menjadi ciri isi dari teks anekdot. Pertama, partisipan adalah orang yang ikut aktif dan berperan dalam suatu kegiatan, jadi didalam teks anekdot itu biasanya orang yang menjadi partisipan itu adalah tokoh yang ada dalam cerita tersebut. Tokoh cerita menempati posisi strategis sebagai pembawa dan penyampaian pesan, amanat, moral atau sesuatu yang sengaja ingin disampaikan kepada pembaca. Kedua, unsur lucu dalam teks anekdot adalah katakata yang mengandung humor dalam teks tersebut baik dalam bentuk narasi ataupun dialog yang bertujuan untuk bersenda gurau, atau menyindir, mengkritik egala bentuk kepincangan dan ketidak beresan yang terjadi di masyarakat penciptanya. Ketiga, kritikan dalam anekdot adalah kritikan yang sering kali disampaikan dalam bentuk sindiran, tidak disampaikan secara langsung. Hal itu dilakukan untuk menghindari konflik diantara pihak yang menyampaikan sindiran dengan pihak yang disindir.

Ketiga, penggunaan EBI yang tepat. Pentingnya penggunaan ejaan dalam sebuah tulisan disebabkan ejaan merupakan aturan dalam memindahkan bunyi bahasa ke bentuk tulisan. Menurut Hasnun (2006:16) mengungkapkan bahwa ejaan adalah kaidah-kaidah cara menggambarkan bunyi-bunyi (kata, kalimat dan sebagainya) dalam bentuk tulisan (huruf-huruf) serta penggunaan tanda baca. Menurut Semi (2009:151), ejaan adalah seperangkat sistem yang digunakan dalam memindahkan bahasa lisan kedalam bahasa tulis. Dalam menganalisis tulisan siswa khususya menulis teks anekdot, penggunaan EBI hanya menggunakan pemakaian huruf kapital, penulisan kata, dan penggunaan tanda baca.

Berdasarkan pengamatan yang telah dilakukan di SMA Negeri 1 Lembah Gumanti, siswa kelas X masih menemui beberapa kendala dalam menulis teks anekdot. Kendala tersebut antara lain (1) siswa dalam menulis teks anekdot belum sesuai struktur, (2) siswa dalam menulis isi teks anekdot belum memuat unsur yang harus ada dalam isi teks, (3) siswa belum matuhi EBI dalam menulis teks anekdot, dan (4) model discovery learning berbantuan media audiovisual belum pernah digunakan. Untuk mengatasi permasalahan tersebut, siswa kelas X SMA Negeri 1 Lembah Gumanti diberikan suatu perlakuan yaitu penggunaan model discovery learning berbantuan media audiovisual terhadap keterampilan menulis teks anekdot. 
Saputra (2016:65) mengatakan bahwa discovery adalah metode belajar yang mendorong siswa untuk mengajukan pertanyaan dan menarik kesimpulan dan prinsip-prinsip umum secara praktis. Selanjutnya, Bell (dalam Hosnan, 2014:281) mengungkapkan bahwa belajar penemuan (discovery) berarti belajar yang terjadi sebagai hasil dari siswa memanipulasi, membuat struktur dan mentransformasikan informasi sedemikian sehingga ia menemukan informasi baru.

Senada dengan pendapat tersebut, Hosnan (2014:282) juga menyatakan bahwa model discovery adalah suatu model untuk mengembangkan cara belajar siswa aktif dengan menemukan sendiri, menyelidiki sendiri sehingga hasil yang diperoleh akan setia dan tahan lama dalam ingatan siswa. Dalam pembelajaran penemuan (discovery), siswa didorong untuk belajar sebagian besar melalui keterlibatan aktif mereka sendiri dengan konsep-konsep dan prinsip-prinsip, dan guru mendorong siswa untuk memiliki pengalaman dan melakukan percobaan yang memungkinkan mereka menemukan prinsip-prinsip untuk diri mereka sendiri (Wilcox dalam Hosnan, 2014:281).

Berdasarkan pendapat tersebut, dapat disimpulkan bahwa model discovery learning adalah suatu model pembelajaran yang terjadi apabila materi pelajaran tidak disajikan dalam bentuk finalnya tetapi siswa disuruh untuk mengorganisasi sendiri. Dalam pembelajaran penemuan, siswa didorong untuk terlibat aktif dalam proses pembelajaran.

Model discovery learning memiliki keunggulan dalam proses pembelajaran. Menurut Kurnianto (2016:35) bahwa model pembelajaran tersebut; (1) dapat menimbulkan rasa senang pada siswa, tumbuhnya rasa menyelidiki dan berhasil; (2) membantu siswa memperkuat konsep dirinya, karena memperoleh kepercayaan bekerja sama dengan orang lainnya; (3) membantu siswa menghilangkan skeptisme; (4) proses belajar menjadikan siswa menuju pada pembentukan manusia seutuhnya; (5) meningkatkan penghargaan pada siswa; (5) dapat mengembangkan bakat dan kecakapan individu.

Selain memiliki keunggulan, model discovery learning juga memiliki kelemahankelemahan. Menurut Maswan (2013:57), model discovery learning memiliki lima kelemahan. Pertama, pada siswa harus ada kesiapan dan kematangan mental untuk cara belajar ini. Siswa harus berani dan berkeinginan untuk mengetahui keadaan sekitarnya dengan baik. Kedua, bila kelas terlalu besar penggunaan metode ini kurang berhasil. Ketiga, bila guru dan siswa sudah biasa dengan perencanaan dan pengajaran tradisional mungkin akan sangat kecewa bila diganti dengan model ini. Keempat, dengan model ini, ada yang berpendapat bahwa proses mental itu terlalu mementingkan proses pengertian saja, kurang memperhatikan perkembangan/pembentukan sikap dan keterampilan siswa. Kelima, model ini mungkin tidak memberikan kesempatan kepada siswa untuk berpikir secara kreatif.

Djamarah dan Zain (2010:123) mengungkapkan bahwa media pembelajaran merupakan salah satu sumber belajar yang berperan serta membantu guru untuk memperkaya wawasan siswa. Salah satu media pembelajaran tersebut adalah media audiovisual. Menurut Djamarah dan Zain (2010:124), media audiovisual adalah media yang mempunyai unsur suara dan unsur gambar.

Selanjutnya, Menurut Ambuko Benson, Florence Odera (Purbowo, Yutmini, dan Anitah, 2014:128) media is expected to play a critical role in enhancing academic performance. (Media diharapkan dapat memainkan peran penting dalam meningkatkan prestasi akademik). Selanjutnya Budi (2014:612-616) mengungkapkan bahwa media adalah alat saluran komunikasi. Salah satu media efektif yang diterapkan dalam pembelajaran yaitu media audiovisual.

Sugiantari (2014:3) mengemungkakan bahwa media audiovisual adalah media instruksional modern yang sesuai dengan perkembangan zaman (kemajuan ilmu pengetahuan dan teknologi), meliputi media yang dapat dilihat, dan didengar. Menurut Djamarah (2010:124), media ini dibagi menjadi dua, yaitu audio visual diam dan audio visual gerak. Audio visual diam adalah media yang menampilkan suara dan gambar diam seperti film bingkai suara (sound slides), film rangkaian suara, dan cetak suara. Sementara itu, audiovisual gerak adalah media 
Hubungan Keterampilan Memahami Teks Cerita Pendek dengan Keterampilan Menulis Teks Cerita Pendek Siswa Kelas XI SMA Semen Padang- Mira Handriyani, Harris Effendi Thahar, Andria Catri Tamsin

yang dapat menampilkan unsur suara dan gambar yang bergerak seperti film suara dan video cassette.

Asri dan Hafrison (2011:31) menyatakan kelebihan penggunaan media audiovisual dalam pembelajaran sebagai berikut. Pertama, penggunaan media audiovisual dapat mengoptimalkan penyajian bahan ajar kepada peserta didik. Kedua, media tersebut dapat memotivasi siswa untuk mempelajari materi yang sedang dipelajari. Ketiga, media audiovisual dapat menggantikan juga guru dalam pembelajaran. Sebagai fasilitator, guru memberikan kemudahan bagi peserta didik untuk belajar. Jayanti (2014:5) mengatakan bahwa media audiovisual dapat mengefektifan proses pembelajaran dan membuat pembelajaran lebih menarik. Selain itu, media audiovisual dapat menjadikan siswa lebih aktif dalam belajar dengan demikian, penggunaan media audiovisual dapat mengoptimalkan proses pembelajaran.

Indriana (2011:92) mengemukakan kelemahan media audiovisual sebagai berikut. Pertama, dari segi biaya, proses pembuatanya cukup mahal. Kedua, dari segi waktu, proses pembutannya menyita waktu. Ketiga, dari segi penggunaan, memerlukan penggelapan ruangan. Keempat, pengoperasiannya hanya dapat dilakukan oleh orang yang lebih paham dengan media tersebut.

Kelebihan-kelebihan tersebut salah satu alasan dipilihnya model discovery learning berbantuan media media audiovisual dalam pembelajaran menulis teks anekdot siswa kelas $\mathrm{X}$ SMA Negeri 1 Lembah Gumanti. Penggunaan model discovery learning berbantuan media audiovisual bertujuan agar siswa mudah memahami dan menemukan struktur, isi, dan penggunaan EBI yang tepat. Selain itu, penggunaan model ini juga menarik perhatian siswa untuk lebih aktif berbicara di depan umum. Dengan demikan, tujuan penelitian ini adalah untuk melihat ada atau tidaknya pengaruh model discovery learning berbantuan media audiovisual terhadap keterampilan menulis teks anekdot siswa kelas X SMA Negeri 1 Lembah Gumanti.

\section{B. Metode}

Jenis penelitian ini adalah penelitian kuantitatif dengan metode eksperimen. Arikunto (2010:10) mengemukakan bahwa penelitian kuantitatif merupakan penelitian yang menggunakan angka dimulai dari pengumpulan data, kemudian penafsiran data dan terakhir hasilnya. Metode yang digunakan dalam penelitian ini adalah metode eksperimen. Metode ini tepat digunakan karena penelitian ini bertujuan untuk melihat pengaruh perlakuan terhadap suatu objek penelitaian. Menurut Ibnu (2003), menyatakan penelitian eksperimental merupakan penelitian yang subjeknya diberi perlakuan kemudian diukur akibat dari perlakuan dari diri subjek. Jenis eksperimen ini adalah quasi eksperimen (eksperimen semu). Menurut Suryabrata (2011:92) eksperimen semu bertujuan untuk memperoleh informasi yang merupakan perkiraan bagi informasi yang dapat diperoleh dengan eksperimen yang sebenarnnya dalam keadaan yang tidak memungkinkan untuk mengontrol dan memanipulasi semua variabel yang relevan.

Penelitian ini dilakukan untuk mengetahui ada atau tidaknya pengaruh model discovery learning berbantuan media audiovisual terhadap keterampilan menulis teks anekdot siswa kelas X SMA Negeri 1 Lembah Gumanti. Indikator penilaian yang digunakan terdiri atas tiga, yaitu kelengkapan struktur teks, ketepatan isi teks, dan penggunaan EBI. Dengan kata lain, hasil tes siswa dinilai berdasarkan ketiga indikator tersebut.

Sampel penelitian ini terdiri atas 1 kelompok.. Sampel yang diambil adalah kelas $\mathrm{Xmipa}_{3}$ dengan jumlah siswa 30 orang dengan alasan kelas tersebut memiliki standar deviasi terendah. Kelompok tersebut diberikan perlakuan berupa tes keterampilan menulis teks anekdot sebelum dan sesudah menggunakan model discovery learning berbatuan media audiovisual.

Data penelitian ini adalah hasil tes keterampilan menulis teks anekdot tanpa dan menggunakan perlakuan. Data yang diperoleh selanjutnya dianalisis melalui langkah-langkah berikut. Pertama, membaca dan memeriksa tulisan teks anekdot yang ditulis siswa. Kedua, 
memberi skor terhadap tulisan teks anekdot siswa. Ketiga, mengubah skor menjadi nilai. Keempat, menafsirkan nilai tanpa dan menggunakan model discovery learning berbantuan media audiovisual berdasarkan rata-rata hitung keterampilan menulis teks anekdot siswa kelas X SMA Negeri 1 Lembah Gumanti. Kelima, mengklasifikasikan hasil keterampilan menulis teks anekdot siswa tanpa dan menggunakan model discovery learning berbantuan media audiovisual berdasarkan skala 10. Keenam, menampilkan tingkat keterampilan menulis teks anekdot siswa kelas X SMA Negeri 1 Lembah Gumanti tanpa dan menggunakan model discovery learning baik secara umum maupun per indikator dalam bentuk diagram. Ketujuh, pengujian hipotesis. Sebelum uji hipotesis, dilakukan uji persyaratan analisis, yaitu uji normalitas dan uji homogenitas. Pengujian hipotesis dilakukan dengan cara membandingkan tingkat keterampilan menulis teks anekdot tanpa dan menggunakan model discovery learning berbantuan media audiovisual. Kedelapan, menganalisis dan membahas hasil penelitian. Kesembilan, menyimpulkan hasil pembahasan.

\section{Hasil dan Pembahasan}

Dalam hasil dan pembahasan ini akan dijelaskan keterampilan menulis teks anekdot tanpa dan menggunakan model discovery learning berbantuan media audiovisual serta menjelaskan bagaimana pengaruhnya terhadap keterampilan menulis teks anekdot siswa kelas X SMA Negeri 1 Lembah Gumanti.

\section{Keterampilan Menulis Teks anekdot Siswa Kelas $X$ SMA Negeri 1 Lembah Gumanti tanpa Menggunakan Model Discovery Learning Berbantuan Media Audiovisual}

Berdasarkan analisis data diperoleh rata-rata hitung keterampilan teks anekdot siswa kelas SMA Negeri 1 Lembah Gumanti tanpa menggunakan model discovery learning berbantuan media audiovisual sebesar 75,97 Dari rata-rata hitung tersebut dapat disimpulkan bahwa keterampilan menulis teks anekdot tanpa menggunakan model discovery learning berbantuan media audiovisual tergolong Lebih dari Cukup.

Rata-rata hitung dan KKM digunakan sebagai tolak ukur untuk menentukan keterampilan menulis teks anekdot siwa kelas X SMA Negeri 1 Lembah Gumanti tanpa menggunakan model. discovery learning berbantuan media audiovisual. Besarnya/KKM untuk mata pelajaran bahasa Indonesia di SMA Negeri 1 Lembah Gumanti adalah 75.

Keterampilan menulis teks anekdot siswa kela X SMA Negeri 1 Lembah Gumanti tanpa menggunakan model discovery learning berbantuan media audiovisual dapat dilakukan dengan analisis per indikator. Nilai rata-rata tertinggi dari ketiga indikator keterampilan menulis teks anekdot tanpa menggunakan model discovery learning adalah indikator penulisan struktur teks anekdot (1), yaitu 70,00 (LdC) dan nilai rata-rata terendah adalah indikator isi (2), yaitu 60,00 (Cukup). Karena indikator penulisan struktur teks anekdot (1) lebih tingi dibandingkan dengan indikator lainnya, indikator struktur teks anekdot sudah mencapai KKM (1) Kemendikbud (2013:101) membagi stuktur teks anekdot menjadi lima bagian antara lain. (1) abstraksi, (2) orientasi, (3) krisis, (4) reaksi, dan (5) koda.

Nilai rata-rata isi dalam teks teks anekdot (2), tanpa menggunakan model discovery learning berbantuan media audiovisual adalah 60,00 (Cukup). Menurut Kemendikbud (2015: 83-84), untuk menulis teks anekdot diperlukan partsiipan, unsur lucu atau kelucuan yang biasanya disampaikan dengan bahasa yang singkat, tetapi mengena.

Nilai rata-rata untuk indikator penggunaan Ejaan Bahasa Indonesia (EBI) dalam teks anekdot (3) tanpa menggunakan model discovery learning berbantuan media audiovisual 76,56 (Baik). Hal ini disebabkan oleh terbatasnya pengetahuan siswa tentang EBI sehingga teks anekdot yang ditulis oleh siswa belum sesuai dengan aturan EBI yang sudah ditetapkan. Menurut Semi (2007:151) ejaan adalah seperangkat sistem yang digunakan dalam memindahkan bahasa lisan ke dalam bahasa tulis. Di dalam ejaan ini, tercakup sistem penulisan 
Hubungan Keterampilan Memahami Teks Cerita Pendek dengan Keterampilan Menulis Teks Cerita Pendek Siswa Kelas XI SMA Semen Padang- Mira Handriyani, Harris Effendi Thahar, Andria Catri Tamsin

huruf, penulisan kata, penulisan unsur serapan, dan penggunaan tanda baca. Dalam penelitian ini hanya tiga hal yang dinilai dari unsur ejaan yaitu penulisan huruf kapital, preposisi atau kata depan dan penggunaan tanda baca dalam teks anekdot siswa.

\section{Keterampilan Menulis Teks anekdot Siswa Kelas X SMA Negeri 1 Lembah Gumanti Menggunakan Model Discovery Learning Berbantuan Media Audiovisual}

Berdasarkan analisis data diperoleh rata-rata hitung keterampilan teks anekdot siswa kelas SMA Negeri 1 Lembah Gumanti menggunakan model discovery learning berbantuan media audiovisual sebesar 84,17. Dari rata-rata hitung tersebut dapat disimpulkan bahwa keterampilan menulis teks anekdot menggunakan model discovery learning berbantuan media audiovisual tergolong (B). Hal ini disebabkan model discovery learning berbantuan media audiovisual membantu siswa memperbaiki dan meningkatkan keterampilan-keterampilan dan proses-proses kognitif. Usaha penemuan merupakan kunci dalam proses ini.

Kedua, kelas yang menggunakan model discovery learning berbantuan media audiovisual pada penulisan struktur secara keseluruhan memuat lima dari lima sub aspek, yaitu abstraksi, orientasi, krisis, dan koda. Namun, ada juga yang belum menuliskan struktur teks anekdot dengan lengkap. Siswa yang menuliskan lima dari lima sub aspek penulisan struktur teks anekdot berjumlah 11 orang $(36,67 \%)$ dan siswa yang menuliskan empat dari lima sub aspek berjumlah 6 orang (20,00\%). Untuk lebih jelasnya, data ini dapat dilihat pada Lampiran.

Kedua, untuk indikator isi teks anekdot dalam tulisan siswa menggunakan model discovery learning, siswa sudah terampil menulis dengan menggunakan isi yang benar. Dibuktikan dari skor yang diperoleh siswa untuk indikator isi dalam teks anekdot (2). Siswa yang memperoleh skor 4 berjumlah 4 orang (13,33\%). Siswa yang memperoleh skor 3,5 berjumlah 16 orang (53,33\%). Siswa yang memperoleh skor 3 berjumlah 4 orang $(13,3 \%)$. Siwa yang memperoleh skor 2,5 berjumlah 4 orang (13,33\%), siswa yang memperoleh skor 2 berjumlah 2 (6,67\%). Untuk lebih jelasnya, data tersebut dapat dilihat pada lampiran.

Ketiga, siswa sudah terampil menggunakan EBI dengan benar. Namun, ada juga siswa yang belum menuliskan EBI dengan benar. Dibuktikan dari skor yang diperoleh siswa untuk indikator penggunaan EBI dalam teks anekdot (4). Untuk indikator 4 siswa yang memperoleh skor 4 berjumlah 10 orang (33,33\%). Siswa yang memperoleh skor 3,5 berjumlah 13 orang $(43,33 \%)$. Siswa yang memperoleh skor 3 berjumlah 6 orang $(20,00 \%)$. Siswa yang memperoleh skor 2 berjumlah 1 orang (3,33\%). Untuk lebih jelasnya, mengenai data tersebut, dapat dilihat pada Lampiran

Berdasarkan uraian tersebut, dapat disimpulkan bahwa keterampilan menulis teks anekdot menggunakan model discovery learning berbantuan media audiovisual lebih tinggi dibandingkan dengan tanpa menggunakan model discovery learning berbantuan media audiovisual untuk ketiga indikator. Hal tersebut dibuktikan dengan nilai rata-rata keseluruhan siswa menggunakan menggunakan model discovery learning berbantuan media audiovisual lebih tinggi $(84,17)$ dibandingkan dengan nilai tanpa menggunakan model discovery learning berbantuan media audiovisual $(75,97)$.

Untuk lebih jelasnya mengenai pembahasan keterampilan menulis teks anekdot menggunakan model discovery learning berbantuan media audiovisual dapat dilihat dari analisis per indikator. Nilai rata-rata tertinggi dari keempat indikator keterampilan menulis teks anekdot adalah indikator EBI (3) dalam teks anekdot adalah 87,92. Artinya, untuk indikator EBI (3) dalam teks anekdot sudah mencapai KKM. Hal ini disebabkan dalam pembelajaran menulis teks anekdot dalam menggunakan model discovery learning berbantuan media audiovisual siswa diajarkan untuk memaparkan isi teks anekdot dengan memperhatikan ejaan dengan benar. Pada indikator ini semua siswa sudah terampil menuliskan ejaan dengan benar dalam setiap kata yang terdapat pada teks anekdot.

Nilai rata-rata keterampilan menulis teks anekdot siswa kelas X SMA Negeri 1 Padang menggunakan model discovery learning berbantuan media audiovisual untuk indikator 
struktur teks anekdot (1) adalah 82,92. Hal ini disebabkan dalam pembelajaran menulis teks anekdot pada kelas yang menggunakan model discovery learning berbantuan media audiovisual siswa diperkenalkan dengan struktur-struktur tek anekdot dengan berbagai pertanyaan-pertanyaan mendasar sehingga siswa lebih mudah menentukan struktur teks anekdot. Penentuan pertanyaan mendasar tersebut yang dilakukan dengan melakukan pertanyaan-pertanyaan kepada siswa dan menyediakan contoh-contoh yang berkaitan dengan penulisan teks anekdot. Pada indikator ini siswa sudah mampu menuliskan truktur teks anekdot dengan baik. Kemendikbud (2013:38) menyatakan model discovery learning dalam pembelajaran memiliki sepuluh kelebihan.

Nilai rata-rata untuk indikator isi dalam teks anekdot (2), kelas menggunakan model model discovery learning adalah 81,67. Artinya siswa sudah terampil menuliskan isi teks anekdot dengan benar, dan sudah mencapai KKM ketuntasan.

\section{Pengaruh Model Discovery Learning Berbantuan Media Audiovisual terhadap Keterampilan Menulis Teks Anekdot Siswa Kelas X SMA Negeri 1 Padang}

Ditinjau dari hasil tes keterampilan menulis teks anekdot siswa, hasil keterampilan menulis teks anekdot menggunakan model discovery learning berbantuan media audiovisual lebih tinggi dibandingkan dengan tanpa menggunakan model discovery learning berbantuan media audiovisual. Hal ini terbukti dari hasil penelitian yang menunjukkan bahwa keterampilan menulis teks anekdot siswa kelas X SMA Negeri 1 Lembah Gumanti menggunakan model discovery learning berbantuan media audiovisual berada pada kualifikasi Baik (B) dengan nilai rata-rata 84,17, sedangkan keterampilan menulis teks anekdot tanpa menggunakan model discovery learning berbantuan media audiovisual siswa kelas X SMA Negeri 1 Lembah Gumanti berada pada kualifikasi Lebih dari Cukup (LdC) dengan nilai rata-rata 75,97. Demikian juga, dengan $u j i$ hipotesis yang dilakukan $t_{\text {tabel }}<t_{\text {hitung }}(1,70<3,28)$ pada taraf signifikan $95 \%$.

Ditinjau dari kelebihan model discovery learning berbantuan media audiovisual sangat baik jika diterapkan dalam pembelajaran teks anekdot. Hal tersebut dikarenakan model pembelajaran berbasis proyek dapat dimaknai sebagai suatu kegaiatan pembelajaran yang bertumpu pada upaya melakasanakan suatu kegiatan atau pekerjaan dengan tujuan khusus dan memiliki saat penyelesaian yang tegas.

Pernyataan ini didukung oleh pendapat Hosnan (2014:282) yang menyatakan bahwa model discovery learning adalah suatu model untuk mengembangkan cara belajar/siswa aktif dengan menemukan sendiri, menyelidiki sendiri sehingga hasil yang diperoleh akan setia dan tahan lama dalam ingatan siswa.

Berdasarkan pendapat tersebut, dapat disimpulkan bahwa model discovery learning adalah suatu model pembelajaran yang terjadi apabila materi pelajaran tidak disajikan dalam bentuk finalnya tetapi siswa disuruh untuk mengorganisasi sendiri. Dalam pembelajaran penemuan, siswa didorong untuk terlibat aktif dalam proses pembelajaran. Penggunaan model discovery learning berbantuan media audiovisual sangat menarik bagi siswa. Hal tersebut terbukti dengan antusias dan bersemangatnya siswa untuk mengikuti pembelajaran. Saat guru memberikan materi dengan menggunakan model model discovery learning berbantuan media audiovisual siswa serta merta serius mengamati materi dan video teks anekdot yang tayangkan. Siswa dapat menulis teks anekdot dengan kata kunci yang sudah ditemukan. Siswa sangat aktif ketika guru bertanya mengenai penulisan struktur, isi, diksi, dan penulisan EBI teks anekdot.

Berdasarkan uraian di atas, disimpulkan bahwa guru sangat berperan penting dalam merencanakan, melaksanakan, mengevaluasi, dan memberikan variasi model serta media pembelajaran kepada siswa agar siswa tidak cepat bosan dalam belajar khususnya menulis teks anekdot. Salah satu upaya tersebut berupa penggunaan model discovery learning berbantuan media audiovisual dalam pembelajaran keterampilan menulis teks anekdot. Perbedaan rata-rata keterampilan menulis teks anekdot tanpa dan menggunakan model discovery learning berbantuan media audiovisual siswa kelas X SMA Negeri 1 Lembah Gumanti, dianggap sebagai pengaruh yang ditimbulkan oleh penggunaan model discovery learning berbantuan media 
Hubungan Keterampilan Memahami Teks Cerita Pendek dengan Keterampilan Menulis Teks Cerita Pendek Siswa Kelas XI SMA Semen Padang- Mira Handriyani, Harris Effendi Thahar, Andria Catri Tamsin

audiovisual yang diberikan pada siswa kelas X SMA Negeri 1 Lembah Gumanti. Dengan demikian, disimpulkan bahwa penggunaan model discovery learning berbantuan media audiovisual berpengaruh secara signifikan terhadap keterampilan menulis teks anekdot siswa kelas X SMA Negeri 1 Lembah Gumanti.

\section{Simpulan dan Saran}

Berdasarkan hasil analisis data dan pembahasan pada Bab IV, dapat disimpulkan bahwa penggunaan model discovery learning berbantuan media audiovisual berpengaruh terhadap keterampilan menulis teks anekdot siswa kelas X SMA Negeri 1 Lembah Gumanti. Dengan kata lain model discovery learning berbantuan media audiovisual dapat diterapkan dalam pembelajaran menulis teks anekdot. Dengan demikian, $\mathrm{H}_{1}$ diterima dan $\mathrm{H}_{0}$ ditolak karena hasil penelitian membuktikan bahwa $t_{\text {tabel }}<t_{\text {hitung. }}$

Berdasarkan simpulan tersebut diajukan saran-saran sebagai berikut. Pertama, guru mata pelajaran bahasa Indonesia dalam proses pembelajaran dapat menggunakan model discovery learning agar siswa lebih tertarik untuk mengikuti pembelajaran bahasa Indonesia sehingga pembelajaran berlangsung dengan efektif.

Kedua, siswa-siswa siswa kelas X SMA Negeri 1 Lembah Gumanti hendaknya giat dalam menulis. Selain itu, menulis teks anekdot memudahkan siswa untuk menggali informasi tentang permaalahan publik yang nantinya bisa ide-ide tersebut dapat tersampaikan melalui teks anekdot. Karena dengan kritikan, kritikan yang berbaur unsur humor itu akan lebih menarik minat baca masyarakat pada umumnya terkhusus dikalangan pelajar yang tidak suka membaca.

Ketiga, peneliti lain hendaknya merancang penelitian yang lebih mendalam tentang pembelajaran menulis teks anekdot. Dengan demikian, diperoleh gambaran yang lebih luas dan mendalam tentang kesiapan mahasiswa sebagai calon guru pengampu mata pelajaran bahasa Indonesia.

Catatan: Artikel ini disusun berdasarkan skripsi Mayora dengan Pembimbing I Prof. Dr. Syahrul R., M.Pd. dan Pembimbing II Dr. Tressyalina, M.Pd.

\section{Daftar Rujukan}

Agustahina, M. (2014). Kemampuan menulis teks anekdot siswa kelas X.1 Madrasah Aliyah Negeri Bintan. Jurnal Studi Sosial 1 (4), 63-78.

Arikunto, S. (2010). Prosedur Penelitian: Suatu Pendekatan Praktik. Jakarta: Rineka Cipta.

Budi, B.A.S. (2014). Penggunaan media audiovisual dengan media gambar terhadap hasil belajar shooting bola basket studi pada siswa kelas VIII SMP Negeri 1 Jatiroto Kabupaten Lumajang. Jurnal Pendidikan Olahraga dan Kesehatan 2 (3), 612-616.

Djamarah, S.B. (2010). Strategi Belajar Mengajar. Jakarta: Rineka Cipta.

Hasnum, A. (2006). Pedoman Menulis untuk Siswa SMP dan SMA. Yogyakarta: Andi Offset.

Hosnan, M. (2014). Pendekatan Santifik dan Kontekstual dalam Pembelajaran Abad 21. Bogor: Ghalia Indonesia.

Ibnu, S. (2003). Dasar- Dasar Metodologi Penelitian. Malang: Universitas Negeri Malang.

Indriana, D. (2011). Ragam Alat Bantu Media Pembelajaran. Yogyakarta: Diva Press. 
Kurnianto, H. (2016). Pengaruh model pembelajaran discovery learning disertai lembar kegiatan siswa (lks) terhadap prestasi belajar siswa pada materi hidrolisis garam kelas XI SMA Negeri 1 Karanganyar tahun pelajaran 2014/2015. Jurnal Pendidikan Kimia 5 (1), 3240.

Kemdikbud. (2015). Bahasa Indonesia Ekspresi Diri dan Akademik SMA/MA Kelas X (Buku Siswa). Jakarta: Kemendikbud RI.

Kemendikbud. (2013). Model-Model Pembelajaran yang Relevan dengan Pengimplementasian Kurikulum 2013 (K13). Buku Ajar. Padang: FBS UNP.

Maswan. (2013). Variasi pembelajaran dalam teknologi instruksional. Jurnal Inkuiri 2 (4), 57-94.

Nuryatin, A. (2016). Peningkatan keterampilan menulis teks anekdot bermuatan kesantunan berbahasa menggunakan model pembelajaran berbasis masalah (problem based learning) pada siswa kelas X MIA-4 SMA negeri 1 Grobogan tahun ajaran 2013/2014. Jurnal Inkuiri 4 (2), 43-50.

Purwono, J., Yutmini, S., Anitah, S.(2014). Penggunaan media audio-visual pada mata pelajaran ilmu pengetahuan alam di sekolah menengah pertama Negeri 1 Pacitan. Jurnal Teknologi Pendidikan dan Pembelajaran 2 (2), 127-144.

Permendikbud. (2015). Pedoman Ejaan Bahasa Indonesia. Jakarta: Kemendikbud.

Saputra, A. (2016). Penerapan discovery learning menggunakan reflika untuk meningkatkan berpikir kritis dan sikap nasionalisme. Jurnal Studi Sosial 4 (1), 61-71.

Sugiantari, N.P.E. (2014). Model pembelajaran generatif berbantuan media audiovisual terhadap hasil belajar IPA siswa kelas V SD gugus V Mengwi. Jurnal PGSD. 2 (1), 3.

Suryabrata, S. (2011). Metodologi Penelitian. Jakarta: Raja Grafindo Persada. Semi, M.A. (2009). Menulis Efektif. Padang: UNP Press.

Wardani, I.K., Winarni, R., Slamet, St.Y. (2017). Studi kasus pembelajaran menulis teks anekdot pada kurikulum 2013 di SMA Negeri 1 Surakarta tahun pelajaran 2016/2017. Aksara 2 (1), 45-57. 